NBER WORKING PAPER SERIES

\title{
VALUATION OF NEW GOODS \\ UNDER PERFECT AND \\ IMPERFECT COMPETITION
}

Jerry A. Hausman

Working Paper No. 4970

\author{
NATIONAL BUREAU OF ECONOMIC RESEARCH \\ 1050 Massachusetts Avenue \\ Cambridge, MA 02138 \\ December 1994
}

Thanks to the NSF for research support, conversations with Z. Griliches and G. Leonard, and helpful comments by T. Bresnahan, P. Joskow, and W. Nordhaus. Jason Abrevaya provided excellent research assistance. This paper is given in the memory of Sir John Hicks who first taught me welfare economics. This paper is part of NBER's research program in Productivity. Any opinions expressed are those of the author and not those of the National Bureau of Economic Research.

(C) 1994 by Jerry A. Hausman. All rights reserved. Short sections of text, not to exceed two paragraphs, may be quoted without explicit permission provided that full credit, including $\odot$ notice, is given to the source. 


\title{
VALUATION OF NEW GOODS \\ UNDER PERFECT AND \\ IMPERFECT COMPETITION
}

\begin{abstract}
The Consumer Price Index (CPI) attempts to answer the question of how much more (or less) income does a consumer require to be as well off in period 1 as in period 0 given changes in prices, changes in the quality of goods, and the introduction of new goods (or the disappearance of existing goods). The CPI has not attempted to estimate the effect of the introduction of new goods, despite the recognition of the potential importance of new goods on a cost-of-living index.

In this paper I first explain the theory of cost-of-living indices and demonstrate how new goods should be included using the classical theory of Hicks and Rothbarth. The correct price to use for the good in the pre-introduction period is the "virtual" price which sets demand to zero. Estimation of this virtual price requires estimation of a demand function which in turn provides the expenditure function which allows exact calculation of the cost of living index. The data requirements and need to specify and estimate a demand function for a new brand among many existing brands requires extensive data and some new econometric methods which may have proven obstacles to the inclusion of new goods in the CPI up to this point. As an example I use the introduction of a new cereal brand by General Mills in 1989-Apple Cinnamon Cheerios. I find that the virtual price is about 2 times the actual price of Apple Cinnamon Cheerios and that the increase in consumers surplus is substantial. Based on some simplifying approximations, I find that the CPI may be overstated for cereal by about $25 \%$ because of its neglect of the effect of new cereal brands.

I then extend the classical Hicks-Rothbarth theory from its implicit assumption of perfect competition to the more realistic situation of imperfect competition among multi-product firms. When I take account of the effect of imperfect competition, I find that the increase in consumer welfare is only $85 \%$ as high as in the perfect competition case so that the CPI for cereal would still be too high by about $20 \%$.
\end{abstract}

Jerry A. Hausman

Department of Economics

E52-271A

Massachusetts Institute of Technology

Cambridge, MA 02139

and NBER 


\section{VALUATION OF NEW GOODS UNDER PERFECT AND IMPERFECT COMPETITION}

Jerry A. Hausman, MIT and NBER ${ }^{i}$

March 30, 1994, Revised June 21, 1994

The economic theory of the Consumer Price Index (CPI) has been well developed, c.f. Polak (1989) The CPI serves as an approximation to an ideal cost-of-living (CLI) index. In turn, the cost of living index answers the question of how much more (or less) income does a consumer require to be as well off in period 1 as in period 0 given changes in prices, changes in the quality of goods, and the introduction or new goods (or the disappearance of existing goods). The CPI as currently estimated by the Bureau of Labor Statistics (BLS) does a reasonable job in accounting for price changes and has begun to attempt to include quality changes. However, the BLS has not attempted to estimate the effect of the introduction of new goods, despite the recognition of the potential importance of new goods on both a cost-of-living index and the CPI, c.f. Fixler (1993).

The omission of the effect of the introduction of new goods seems quite surprising given that most commonly used business strategies can be placed in either of two categories: become the low cost producer of a homogeneous good or differentiate your product from its competitors. The latter strategy has become the hallmark of much of American (and Japanese) business practices. The number of cars, beers, cereals, types of soda, ice creams and yoghurts, appliances such as refrigerators, and cable television programming all demonstrate the ability of firms to differentiate their products successfully. Furthermore, consumers demonstrate a preference for these products since they buy them after introduction in sufficient quantities to make the expected profit positive for the new brands. As the BLS has recognized in its

: Thanks to the NSF for research support, conversations with $Z$. Griliches and G. Leonard, and helpful comments by T. Bresnahan, P. Joskow, and $W$. Nordhaus. Jason Abrevaya provided excellent research assistance. This paper is given in the memory of Sir John Hicks who first taught me welfare economics. 
estimation of the CPI: "If the measurement error is systematic, then a systematic difference may exist between the compute CPI and the true CLI, which would, in turn, affect the measured rate of price change." (Fixler, 1993, p. 3) This paper finds evidence of such a systematic difference which causes the CPI to be overstated by a significant amount due to its neglect of new products. ${ }^{2}$

In this paper I first explain the theory of cost-of-living indices and demonstrate how new goods should be included using the classical theory of Hicks (1940) and Rothbarth (1941). The correct price to use for the good in the pre-introduction period is the "virtual" price which sets demand to zero. Estimation of this virtual price requires estimation of a demand function which in turn provides the expenditure function which allows exact calculation of the CLI. The data requirements and need to specify and estimate a demand function for a new brand among many existing brands requires extensive data and some new econometric method which may have proven obstacles to the inclusion of new goods in the CPI up to this point.

As an example $I$ use the introduction of a new cereal brand by General Mills in 1989--Apple-Cinnamon Cheerios. The cereal industry has been among the most prodigious industries in new brand introduction. My econometric specification permits differing amounts of similarity among cereal brands which is quite important given that Apple-Cinnamon Cheerios are closer to other Cheerios brands than to say Shredded wheat. I find that the virtual price is about 2 times the actual price of Apple-Cinnamon Cheerios and that the increase in consumers surplus is substantial. Based on some simplifying approximations. I find that the CPI may be overstated for cereal by about $25 \%$ because of its neglect of the effect of new cereal brands.

I then extend the classical Hicks-Rothbarth theory from its implicit assumption of perfect competition to the more realistic situation of imperfect

2 The BLS does include new goods after they are introduced. However, this procedure misses the consumer welfare which arises from the introduction of the new good compared to the base period when the good was not being sold in the market. 
competition among multi-product firms. Imperfect competition can be important because introduction of a new brand may allow a multi-product firm to raise the prices of its existing closely-competing brands. When I take account of the effect of imperfect competition, I find that the increase in consumer welfare is only $85 \%$ as high as in the perfect competition case. Nevertheless, the CPI for cereal would still be too high by about $20 \%$. Thus, I conclude that the introduction of new goods is an important topic for which the BLS should attempt to incorporate procedures to evaluate new goods correctly into the CPI. I also find that consumers highly value new goods which provide significantly consumers surplus despite the existence of other brands which compete closely with the new brand.

\section{Valuation of New Goods under Perfect Competition}

Sir John Hicks made one of the first attempts to develop the theory of the evaluation of new goods. In 1940 Hicks considered evaluation of social income and economic welfare using index number theory to consider the effects of rationing and the introduction of new goods. Hicks correctly saw his approach as the basis for the evaluation of real income under these changes. Without completely working out the mathematics Hicks stated that for rationed goods the index numbers need to be altered so that the price used would lead to the amount of the ration. This higher price can be considered the "virtual price" which when inserted into the demand function leads to the observed amount of rationed demand. ${ }^{3}$ For new products Hicks stated that the "virtual" price for periods in which the goods did not exist would "just make the demands for these commodities (from the whole community) equal to zero". (1940, p. 144). Modern economists recognize this price as the shadow or reservation price which used in the demand function sets demand equal to zero. of course, new products in a sense are a special case of rationing where the

3 See J. Neary and K. Roberts (1980) for a modern treatment of rationing using this approach. 
demand for the good is zero. Given the demand function I can solve for the virtual price and for the expenditure (or indirect utility function) function and do correct evaluations of social welfare without needing to use the index number formulae discussed by Hicks. ${ }^{4}$

E. Rothbarth, in a 1941 paper on rationing, put the subject on a firm mathematical footing and introduced the notion that a virtual price arises from the "price system with respect to which the quantities actually consumed are optimum...the 'virtual price system'".5 I use his approach to demonstrate the effect on the price index, or real income, of the introduction of a new good. In period 1 consider the demand for the new good, $x_{n}$, as a function of all prices and income, $y$ :

$$
x_{n}=g\left(p_{1}, \ldots, p_{n-1}, p_{n}, y\right) .
$$

Now if the good were not available in period 0 I solve for the virtual price, $\mathrm{P}^{*} \mathrm{n}$, which causes the demand for the new good to be equal to zero:

$$
0=x_{n}=g\left(p_{1}, \ldots, p_{n-1}, p_{n}^{*}, y\right)
$$

The index number approach, used by both Hicks (1940) and by Rothbarth (1941) then considers the change in real income to be the ratio $\left(p_{n}^{*}\right)\left(x_{n}\right) /$ $\left(p_{n}\right)\left(x_{n}\right)$. While this approach is approximately correct, it does not account for the need to change income $y$ as the price is increased in order to stay on the same indifference curve so that the marginal value of income does not change. Thus, instead of using the Marshallian demand curve in equations

\footnotetext{
4 See Hausman $(1980,1981)$ who uses this approach in the context of female labor supply to do welfare calculations.

5 Rothbarth. one of Keynes' last students, faced internment in the U.K. because of his German nationality during WWII. instead. he volunteered for the British Army where he died during the war. G. Burtless and $I$. Burtless and Hausman (1978), were unaware of Rothbarth's paper when we used the term "virtual income" in solving for demands in non-linear budget set problems. Rochbarth's paper was subsequently pointed out to us by $K$. Roberts.
} 
(1.1) and (1.2), I instead would use the income compensated and utility constant Hicksian demand curve to do an exact welfare evaluation. ${ }^{6}$ In terms of the expenditure function I solve the differential equation from Roy's identity which corresponds to the demand function in equation (1.1) to find the (partial) expenditure function:

$$
y=e\left(p_{1}, \ldots, p_{n-1}, p_{n}, u^{1}\right)
$$

The expenditure function gives the minimum amount of income, $y$, to achieve the level of utility $u^{1}$ which arises from the indirect utility function which corresponds to the demand function of equation (1.1) and the expenditure function of equation (1.3). To solve for the amount of income needed to achieve utility level $\mathrm{u}^{2}$ in the absence of the new good, I use the expenditure function from equation (1.3) to calculate:

$$
y^{*}=e\left(p_{1}, \ldots, p_{n-1}, p_{n}^{*}, u^{1}\right)
$$

The exact cost of living index becomes $P\left(p, p^{*}, u^{1}\right)=y^{*} / y$. Note that to use this approach one must estimate a demand curve as in equation (1.1) which in turn implies the expenditure function and the ability to do the exact welfare calculation of equations (1.3) and (1.4). Thus, the only assumption which is required is to specify a parametric (or non-parametric) form of the demand function.

Diewert (1992) reviews the price index literature and calls the use of the expenditure (or cost) function approach the "economic approach" which he

5 In equation (1.2) income, $y$, is solved out in terms of the utility level, $u^{2}$, to find the Hicksian demand curve given the Marshallian demand curve specification. Hausman (1981) demonstrates this solution procedure.

Hausman (1981) demonstrates how to solve the differential equation which arises from Roy's identity in the case of common parametric specifications of demand. Hausman and Newey (1993) demonstrate how to do the analysis when a non-parametric specification of demand is specified and estimated. 
relates back to the original paper of Konus (1924). Diewert is somewhat skeptical about the usefulness of the economic approach, despite its theoretical elegance, because of the requirement of knowing the consumer's expenditure function. (1992, p. 18) Thus, he believes that the traditional "axiomatic approach" might be more useful. However, in the case of new goods the traditional axiomatic approach offers little or no guidance so that demand curve estimation must be undertaken to estimate the virtual or reservation price. Once the demand curve is estimated, the expenditure function comes for "free" since no additional assumption are required and new goods can be evaluated. ' Thus, the economic approach seems to be the only practical approach to the evaluation of new goods.

A potentially more serious problem with the valuation of new goods is the implicit assumption of perfect competition. Indeed, I have not seen this potential problem mentioned in my review of the literature although Joan Robinson's (1933) book on imperfect competition predates Hicks' (1940) paper. The implicit assumption of perfect competition follows from the assumption that prices of other goods remain the same at marginal cost when the new good is introduced. Under imperfect competition with significant fixed costs and free entry which leads to a zero profit condition, introduction of a new good will lead to somewhat higher prices for existing goods whose demand decreases. This effect will usually be small. A more significant effect arises when the fact that most new products are introduced by multi-product firms is considered. Introduction of a new good will allow the firm to raise its price because some of the demand for its existing product which it will lose will not go to competitors' products, but will instead go to the firm's new product. I will develop the implications of imperfect competition in Section VI, but first I will apply the classical theory of new products under perfect

8 Confusion sometimes arises over whether the entire expenditure function or all demand curves must be estimated. The answer is no under the usual type of separability assumptions (or Leontief aggregation assumptions) which are commonly used in empirical research and are implicit in statistical agencies' calculations of price indices. Thus, only the demand curve for the new good needs to be estimated, not the demand curve for all other goods. 
competition to data from the Ready-to-Eat (RTE) cereal industry, perhaps the foremost industry in the introduction of new goods.

\section{New Product Introductions in the Ready-to-Eat Cereal Industry}

The Ready-to-Eat (RTE) cereal industry has been among the most prodigious introducer of new brands among U.S. industries. 9 In the period 1980-1992 approximately 190 new brands were introduced on a basis of about 160 existing brands. Most new cereal brands, in common with most new product introductions, do not succeed. ${ }^{10}$ Out of the 190 new brands introduced since 1980, over 95 have been discontinued. For instance, of the 27 new brands introduced in 1989 , by 199314 brands had already been discontinued. of the 190 new brands introduced during the 12 year period, only 2 of the 190 brands have a market share (in pounds) of greater than one percent. Still, new brands are important in the sense that about $25 \%$ of all RTE cereal consumption comes from brands introduced within the past 10 years. Thus, cereal company executives belleve that it is quite important to continue to introduce new brands because consumers exhibit a strong preference for continued variety among cereal brands.

Some economists have claimed that this high rate of introduction of new brands is part of an anti-competitive strategy by the cereal companies. ${ }^{11}$

9 Recently, the beer industry has also undergone significant new product introductions with bottled draft beer, dry beers, and ice beers all introduced within about the past 5 years.

10 About $80 \%$ of new product introductions in consumers goods fail. See e.g. Urban et. al (1983).

11 See Schmalensee (1978) and Scherer (1982) who claim that "brand proliferation" served as an entry deterrent in the RTE cereal industry. Both economists testified for the U.S. Federal Irade Commission (FTC) "In the Matter of Kellogg Co. et. al.". Docket No. 8883. The FTC lost this "shared monopoly" case in which it was claimed that a highly concentrated oligopoly deterred entry through the introduction of new brands. Furthermore, Judd (1985) subsequently demonstrated that the pre-emption story implied by brand proliferation is unlikely to provide credible pre-emption unless exit costs are high which is contrary to fact in the RTE cereal industry for a given brand. 
While both economic theory and the facts of the industry seem contrary to the pre-emption claim, the RTE cereal industry is highly concentrated with no successful entry by a significant manufacturer in the past 50 years. Six firms have each produced $94 \%$ or higher of all RTE cereals (dollar sales) over the period 1982-92. Kellogg's share has varied in the range of $37.3 \%-41.5 \%$; General Mills' share has varied from 23.0\%-29\%; General Foods' share has varied in the range 10.4\%-15.8\%. Quaker, Ralston and Nabisco have all been in the range of about 3.0\%-8.9\%. Only one other company, Malt-O-Meal, has gained a share above $1 \%{ }^{12}$ Recently, a move toward further consolidation has occurred. In 1992 General Mills announced a purchase of Nabisco's cereal brands, the largest of which is Nabisco Shredded wheat. The U.S. Government did not grant permission for this acquisition, and in 1993 General Foods (Post brands) acquired Nabisco's cereal brands. Thus, 5 major firms are likely to exist although I would not be surprised if another acquisition occurred soon. ${ }^{13}$

However, while the 3 largest firms have about $80 \%$ of the RTE cereal market, it is important to realize that very.few individual brands have significant shares. For instance, Kellogg's Frosted Flakes is the largest Kellogg's brand with a share of $5.0 \%$ (in 1993) with Kellogg's Corn Flakes quite close at $4.99 \%$ while Cheerios is the largest General Mills brand with a share of $5.3 \%$. Most brands have quite a small share and the share movement among brands is quite dynamic.

No successful entry by a significant new manufacturer has occurred in the RTE cereal industry in the past 50 years. The RTE industry has remained highly concentrated during this time period despite the general perception that investments in the RTE cereal industry earn higher rates of return than

$: 2$ However, no individual brand of Malt-0-Meal has ever achieved $1 \%$. Furthermore, much of Malt-O-Meal's production is for private label brands.

13 The State of New York is currently challenging General Food's acquisition of Nabisco so an extremely small probability exists that Nabisco may become independent again, raising the number of competitors to 6 . 
in many other industries. ${ }^{4}$ During the $1970 ' \mathrm{~s}$, some new entry did occur in the RTE cereals industry, for "natural" cereals and by some substantial food product manufacturers such as Pillsbury, Pet, and Colgate, but these firms did not remain for long as competitors. Thus, the prospect for actual new entry into the RTE cereal industry is very unlikely with exit a more likely prospect than new entry despite high growth rates in the $1982-92$ period with an average revenue growth of $6.7 \%$ per year (in real terms).

Since. I do not believe that the brand proliferation models yield a credible model of entry deterrence, what is the main reason for the lack of new entry into an industry which otherwise might expect significant new entry? The main impediment to successful new entry into the RTE cereal market is the necessity for an extremely large investment in advertising, all of which is a sunk cost if the new entrant does not succeed. ${ }^{15}$ Industry estimates are that for current firms to launch a new brand costs between $\$ 20-40$ million in the initial year for advertising and promotion. The investment is typically continued at this level annually for a $1-2$ year period unless the brand is discontinued or allowed to decline because of a decision that the brand will not succeed in the long run. The cumulative investment is expected to be paid off (before any net positive return to the investment is obtained) only after a period of 1-2 years, although a very few brands do succeed more quickly. This investment is substantial compared to the likely success--a $1 \%$ share for a new brand is considered to be a great success. Yet almost no new brand achieves 1\%. Of the approximately 190 new brands which have been introduced during 1982-92, only two currently have a pound share of $1 \%$ or greater.

14 See e.g., 1992 General Mills Annual Report, p. 2 which reports an average after-tax return on capital over five years of $21 \%$, "which is among the best in U.S. industry"; Kellogg's 1991 Annual Report, p. 16, gives an after tax return on assets of about $15.5 \%$ for 1991, while Kellogg's Second Quarter Report for the first six months of 1992 yields an annualized return on assets of $17.7 \%$. Of course, accounting returns on assets are typically an unreliable guide to economic returns; nevertheless, the cereal industry is widely perceived to be quite profitable.

$15 \mathrm{~J}$. Sutton (1991) analyzes a model where endogenous advertising costs provide the main barrier to entry in the RTE cereal industry. 
Thus, the odds of a successful new brand introduction by an existing RTE manufacturer are daunting; a new entrant would face even longer odds because of startup costs and the extra cost and difficulty in achieving shelf space for a new brand. An existing manufacturer can "trade" shelf space from an old brand to a new brand. However, a new entrant does not have the shelf space to trade. The main "outside" competition which has arisen over the past few years has been the success of "store brands", also called private label brands. ${ }^{16}$ Private label brands have doubled their market share from about $4 \%$ to $8 \%$ over the past $5-10$ years. Here the supermarket provides the shelf space and has the cereal manufactured independently. Indeed, Ralston does the majority of the private brand manufacturing. Thus private label corn flakes and other brands seem most successful in providing competition by doing the opposite of the brand proliferation model. ${ }^{17}$ The private label brands do little advertising and position themselves identically to existing brands while offering a lower price to consumers and higher profit margin to the stores. This success of the private label brands provides limited support for the theory that large sunk costs of advertising provide the primary barrier to entry into the cereal industry.

Thus, the high rate of new brand introduction is not part of an anticompetitive strategy in my view. Still, many economists might well doubt the social value of these new brands, the vast majority of which do not succeed. To concentrate the debate, I consider the value to consumers of the introduction of Apple-Cinnamon Cheerios by General Mills in 1989. I choose this brand because it is in some sense close to existing General Mills brands- Cheerios is the largest General Mills brand while Honey-Nut Cheerios already exist. Thus, an empirical question certainly exists of whether consumers

i6 Sutton (1991) in his analysis of competition in the cereal industry finds only limited competition from private label brands which seems contrary to recent developments within the RTE cereal industry.

:7 Economists for the FTC also claimed that entry was difficult due to the economies of scale in cereal manufacturing which would require several successful brands by a new entrant. They failed to consider contract manutacturing of the type done by Ralston for private label brands. 
place much value on the new brand or whether it is already "spanned" by existing brands and so incurs very little new value to consumers.

III. An Empirical Model of Brand Choice in the RTE Cereal Industry

I now proceed to estimate an empirical model of brand choice using a three level model of demand. The top level is the overall demand for cereal using a price index for cereal relative to other goods. The middle level of the demand system estimates demand among various market segments, e.g. the adult segment or children segment. The bottom level is choice of brand, e.g. Cheerios, conditional on a given segment expenditure. Overall price elasticities are then derived from the estimates in all three segments. While this demand structure places restrictions on the overall pattern of substitution across brands, it is considerably less restrictive than other demand approaches typically used to estimate the demand for differentiated products. Clearly, some restrictions are required given the over 100 brands of cereals available in the marketplace. The approach also allows for convenient tests of the overall specification of brand segments within the model, c.f. Hausman et. al. (1994) for the testing methodology.

The data used to estimate the model is cash register data collected on a weekly basis across a sample of stores in major metropolitan areas of the U.S. over a two year period. Thus, exact price and quantity data are available with consider price variation present due to promotions and coupons available to customers. The panel structure of the data--approximate 140 times series observations on each brand across 7 SMSA's-allows for quite precise estimation. The panel data also permits identification and instrumental variable estimation under relatively weak assumptions. Thus, the estimated demand structure should allow a precise estimate of the virtual price for a new cereal brand.

In terms of actual estimation I proceed to estimate the model in reverse order beginning at the lowest level and then use the theory of price indices 
to allow for consistent estimation at the higher (more aggregate) levels of demand. The third (or lowest) stage determines buying behavior within market segments. I use this approach because it accords with segmentation of brand purchasing behavior which marketing analysts claim arises with purchasing behavior, and because it limits the number of cross elasticities which will be estimated. My econometric specification at the lowest level is the "almost ideal demand system" of Deaton and Muellbauer which allows for a second order flexible demand system, i.e., the price elasticities are unconstrained at the point of approximation, and also allows for a convenient specification for non-homothetic behavior. ${ }^{18}$ However, my experience is that the particular form of demand specification is not crucial here. Use of a flexible demand system allows for few restrictions on preferences while decreasing the number of unknown parameters through the use of symmetry and adding up restrictions from consumer theory. For each brand within the market segment the demand specification is:

$$
\begin{gathered}
s_{1 n t}=\alpha_{1 n}+\beta_{1} \log \left(y_{G n t} / P_{n \tau}\right)+\sum_{j=1}^{J} \gamma_{1,} \log p_{j n t}+\epsilon_{i n t}, \\
i=1, \ldots, J \quad n=1, \ldots, N \quad t=1, \ldots, T
\end{gathered}
$$

where $s_{i n t}$ is the revenues share of total segment expenditure of the $i$ th brand in city $n$ in period $t, y_{G n t}$ is overall segment expenditure, $P_{n t}$ is a price index, and $p_{j n t}$ is the price of the $j$ th brand in city $n$. Note that a test of whether $\beta_{\mathfrak{l}}=0$ allows for a test of segment homotheticity, e.g., whether shares are independent of segment expenditure. The estimated $\gamma_{i j}$ permit a free pattern of cross-price elasticities and slutsky symmetry can be imposed, if desired, by setting $\gamma_{i j}=\gamma_{j i}$. This choice of the bottom level demand specification does not impose any restrictions on competition among brands within a given segment. In particular, no equal cross elasticity-type

18 See A. Deaton and J. Muellbauer, "An Almost Ideal Demand System", American Economic Review, 70,1981 , and Economics and Consumer Behavior, (Cambridge: Cambridge University Press. 1980) 
assumptions restrict the within segment cross price elasticities. Since competition among differentiated products is typically "highest" among brands within a given segment, this lack of restrictions can be an important feature of the model. An important econometric consideration is the use of segment expenditure, $y_{G n t}$, in the share specification of equation ( 3.1 ), rather than the use of overall expenditure. Use of overall expenditure is inconsistent with the economic theory of multi-stage budgeting, and it can lead to decidedly inferior econometric results.

Given the estimates from equation (3.1), I calculate a price index for each segment and proceed to estimate the next level of demand. For exact twostage budgeting, the Gorman results impose the requirement of additive separability on the next level. ${ }^{19}$ To specify the middle level demand system I use the $\log -\log$ demand system: ${ }^{20}$

$$
\begin{aligned}
\log q_{\operatorname{mint}} & =\beta_{m} \log y_{B n t}+\sum_{k=1}^{k} \delta_{k} \log \pi_{k n t}+\alpha_{m n}+\epsilon_{m n t} \\
m & =1, \ldots, M \quad n=1, \ldots, N \quad t=1, \ldots, T
\end{aligned}
$$

where the left hand side variable $q_{m n}$ is log quantity of the mth segment in city $n$ in period $t$, the expenditure variable $y_{B n t}$ is total cereal expenditure, and the $\Pi_{k n t}$ are the segment price indices for city $n$. The segments that $I$ use are adult which includes brands such as Shredded wheat and Grape Nuts, the children segment which includes $K i x$ and sugar coated cereals and the family

i9 W. Gorman (1971), "Two Stage Budgeting," mimeo. This subject is also discussed in C. Blackorby, et. al., (1978), Duality Separability and Functional Structure (New York: American Elsevier) and in Deaton and Muellbauer (1980), op. cit. Note that the almost ideal demand system is a generalized Gorman polar form (GGPF) so that Gorman's theorem on exact two stage budgeting applies. Since the additive demand specification at the top level imposes separability restrictions, we have also used a less restrictive specification at the middle level which is not necessarily consistent with exact two-stage budgeting. The results are quite similar.

20 Note that this specification is second-order flexible. However, the Slutsky restrictions have not been imposed on the specification. 
segment which includes Cheerios, Corn Flakes, and other similar brands. The price indices $\Pi_{k n t}$ can be estimated either by using an exact price index corresponding to equation ( 3.1 ), which is constructed from the expenditure function for each segment holding utility constant, or by using a weighted average price index of the Stone-Laspeyres type. Choice of the exact form of the price index does not typically have much influence on the final model estimates.

Lastly, the top level equation, which I use to estimate the overall price elasticity of cereal, is specified as:

$$
\log u_{\tau}=\beta_{0}+\beta_{1} \log y_{t}+\beta_{2} \log \square_{t}+z_{z} \delta+\epsilon_{\tau}
$$

where $u_{t}$ is overall consumption of cereal, $y_{t}$ is deflated disposable income, $\Pi_{t}$ is the deflated price index for cereal, and $z_{t}$ are variables which account for changes in demographics, and monthly (seasonal) factors. To estimate equation (3.3) I use national (BLS) monthly data over a sixteen year period with instrumental variables. I have found that a longer time period than may be available from store level data is often useful to estimate the top level demand elasticity. The instruments I use in estimation of equation ( 3.3 ) are factors which shift costs such as different ingredients, packaging, and labor.

I now consider the question of identification and consistent estimation of the middle level and bottom level equations. The problem is most easily seen in equation ( 3.1 ), the brand level equation, although an analogous problem arises in equation (3.2) the segment level demand equation. Equation (3.1) for each brand will have a number of prices included for each brand in the segment, e.g., I include 9 brands in the family segment in the subsequent estimation. The usual strategy of estimating demand equations where the cost function includes factor input prices, e.g., material prices, which are excluded from the demand equations to allow for identification and the application of instrumental variables may be difficult to implement. An 
insufficient number of input prices may exist or they may not be reported with high enough frequency to allow for instrumental variable estimation. To help solve this problem. I exploit the panel structure of my data. For instance, suppose N - 2 so that weekly or monthly data from two cities is available. Note that I have included brand (or segment) and city fixed effects in the specification of equations (3.1) and (3.2). Now suppose I can model the price for a brand $i$ in cicy $n$ in period $t$ as

$$
\log p_{j n t}=\delta, \log c_{j t}+\alpha_{j n}+w_{y n t}
$$

where $p_{\text {fnt }}$ is the price for brand $j$ in city $n$ in period $t$. The determinants of the brand price for brand $j$ are $c_{j t}$, the cost which is assumed not to have a city specific time shifting component which is consistent with the national shipments and advertising of most differentiated products, $\alpha_{j n}$, which is a city specific brand differential which accounes for transportation costs or local wage differentials, and $w_{j n t}$, which is a mean zero stochastic disturbance which accounts of sales promotion run for brand $j$ in city $n$ in time period $t$. The specific identifying assumption that I make is that the $w_{\text {jnt }}$ are independent across cities. ${ }^{21}$ Using fixed effects the city specific components are eliminated, and I am basically applying the Hausman-Taylor (1981) technique for instrumental variables in panel data models. ${ }^{22}$ The idea is that prices in one city (after elimination of city and brand specific effects) are driven by underlying coses, $c_{j t}$, which provide instrumental variables which are correlated with prices but are uncorrelated with stochastic disturbances in the demand equations, e.g., $w_{j n t}$ from equation (3.4) is uncorrelated with $\epsilon_{: 1 t}$ from equation (3.1) when the cities are

\footnotetext{
21 Note that the $w_{i n t}$ are permitced to be correlated within a given city.

22 See also Breusch, Mizon, and Schmidt (1989). :ith more than two cities, tests of the instrumental variable assumptions can be done along the lines discussed in Hausman and Taylor (1981).
} 
different, $n \sim 1$. Thus, the availability of panel data is a crucial factor which allows for estimation of the all the own price and cross price brand elasticities.

However, another interpretation can be given to equation (3.4) and the question of whether $w_{j n t}$ from equation (3.4) is uncorrelated with $\epsilon_{j 1 t}$ from equation (3.1). To the extent that supermarkets set their prices $p_{j n t}$ under a constant marginal cost assumption (in the short run) and do not alter their prices to equilibrate supply and demand in a given week, prices $p_{\text {jnt }}$ may be considered predetermined with respect to equation (3.1). If prices can be treated as predetermined, then IV methods would not be necessarily needed. IV methods might still be required for the segment expenditure variable $y_{G n t}$ in equation ( 3.1 ), however. The need for instruments under these hypotheses can be tested in a standard procedure using specification tests for instruments, e.g. Hausman (1978).

\section{Data and Results}

The data used to estimate the empirical model of brand choice in the RTE cereal industry are panel data from Nielsen Scantrak. The time series consists of 137 weekly observations from January 1990 to August $19922^{23}$ The cross section is from 7 SMSAs, including Boston, Chicago, Detroit, Los Angeles, New York City, Philadelphia, and San Francisco. In each SMSA Nielsen's sample frame is a stratified random sample of supermarkets which captures the vast majority of all cereal sold. The data are collected on a SKU (stock keeping unit) basis so that the volume of sales of each package size of each brand at an average weekly price is recorded. I aggregate the data across packages so that the quantity variable is weekly sales, in pounds, for each brand at a weekly average price per pound.

The empirical specification requires specification of brand segments. I

23 Estimation was also undertaken using monthly, rather than weekly, data. The estimated elasticities based on monthly data are quite similar to the weekly data estimates, although the precision of the estimates is lower. 
choose 3 brand segments which correspond to common segmentation used in the cereal industry by marketing analysts. ${ }^{24}$ Apple-Cinnamon Cheerios is placed in the family segment. The other two segments used are adult cereals and children's cereals. Some common brands which are placed into the three segments are given below:

\section{Table 1: Segmentation of the Brands}

Adult

Shred Whe Sq

Special K

Fruit Wes

Shred We

Shred We \& Brn

Spn Sze Shred We

Grape Nuts

\section{Child}

Trix

Kix

Frosted Flks

Froot Loops

\author{
Family \\ Cheerios \\ Honey-Nut Cheerios \\ Apple-Cinnamon Cheerios \\ Corn Flakes \\ Raisin Bran (Kelloggs) \\ Rice Krispies \\ Frosted Mini-Wheats \\ Frosted wheat Squares \\ Raisin Bran (Post)
}

To estimate the model for Apple-Cinnamon Cheerios, I focus on the family segment. The family segment represents about $26.4 \%$ of sales in the RTE cereal market.

To highlight further the family segment, I include some descriptive statistics for the family segment in Table 2 .

24 However, some choice of segmentation is required to apply the demand system discussed above. However. I have applied the tests of segmentation discussed in the last section with the specification used not rejected by the Hausman specification tests. 
Table 2: Descriptive Statistics for Family Segment--1992

$\begin{array}{llll}\text { Brand } & \text { Company } & \text { Avg Price } & \text { Segment Share } \\ \text { Cheerios } & \text { Gen Mills } & 2.644 & 21.62 \% \\ \text { HN Cheerrios } & \text { Gen Mills } & 3.605 & 15.03 \% \\ \text { AC Cheerios } & \text { Gen Mills } & 3.480 & 6.19 \% \\ \text { Corn Flakes } & \text { Kellogg } & 1.866 & 14.24 \% \\ \text { Raisin Bran } & \text { Kellogg } & 3.214 & 13.11 \% \\ \text { Rice Krispies } & \text { Kellogg } & 2.475 & 13.54 \% \\ \text { Frosted Miniwts } & \text { Kellogg } & 3.420 & 9.07 \% \\ \text { Frosted Wt Sq. } & \text { Nabisco } & 3.262 & 1.48 \% \\ \text { Raisin Bran } & \text { Post } & 3.046 & 5.72 \%\end{array}$

Table 2 demonstrates the popularity overall of Cheerios--the 3 brands have 42.847 share of the family segment or about a 11.37 share of overall cereal sales. However, Apple-Cinnamon Cheerios has a $6.19 \%$ share of the family segment or a $1.6 \%$ share of overall cereal sales. Thus, the introduction of Apple-Cinnamon Cheerios was quite successful by industry standards.

I now turn to estimation of the bottom level of the demand system which is brand choice for family segment brands. The results are included in Table 3 where fixed effects are used for each SMSA, along with expenditure in this segment, prices for each of the brands, and a display variable. HausmanTaylor (1981) IV estimation is used along with an unrestricted variance matrix for the stochastic disturbances (Seemingly Unrelated Regression). Note that own price coefficient estimates are generally precisely estimated. Most of the cross price effects are also of the expected sign and are generally precisely estimated. Homotheticity of brand choice, which would be a zero coefficient on the expenditure variable, is rejected and not imposed. However, Slutsky symmetry is not rejected so it is imposed on the model specification.

In Table 4 I now turn to segment estimates with a similar model 
specification including SMSA effects, overall cereal expenditure, and stone price indices for each segment along with a display variable for that segment. Here the dependent variable is sales in pounds so that I find that adult cereals have an expenditure elasticity less than unity while children's cereals have an expenditure elasticity which exceeds unity, while family cereals are not different than unity. Segment own price elasticities are found to be sizeable, around -2.0 , while segment cross price elasticities are also found to be large and significant. Thus, overall I find significant competition across cereal brands.

In Table 5 I calculate the conditional elasticities for the family segment, where I condition on expenditure in this segment. Note that the 3 brands of Cheerios provide significant brand competition for each other which is consistent with "cannibalization" fears of brand managers. In Table 6 I estimate overall brand elasticities for the family segment after I estimate the top level of the demand specification where I estimate the overall price elasticity for RTE cereal from the top level demand equation to be -0.90 (a.s.e. $=0.10)$.

Using these estimates I now calculate the virtual price for AppleCinnamon Cheerios as the price at which its market share is zero. I use two methods to calculate the virtual price where I draw graphs of the conditional demand curves using predicted values from the bottom level segment of the demand model. The results vary somewhat depending on the aggregation technique chosen. ${ }^{25}$ The results are found in the graphs in Figures 1 and 2. The estimated virtual, or reservation prices, varies across cities from about $\$ 6.00$ to about $\$ 7.50$. My best estimate of the aggregate reservation price is \$7.14. The asymptotic standard error of the virtual price estimate is $\$ 1.33$ with the lower bound of an (approximate) 95\% confidence interval estimated at $\$ 4.75$ which is $35 \%$ greater than the average price of Apple-Cinnamon Cheerios.

25 The first method uses the average of the right hand side variables for the demand function across all 959 observations to solve for the virtual price. The second method solves for the virtual prices of each of the 959 observations and the average of these prices is used. The results differ because of the non-linearity of the demand system specification used. 
Estimating the consumers surplus from the relevant expenditure functions, which is approximately equivalent to calculating the area under the demand curve to the average price of $\$ 3.48$, yields an estimate of (exact) consumers surplus of $\$ 32,268$ on a per-city, weekly average. The (asymptotic) standard error of the estimate of $\$ 32,267$ is $\$ 3,384$ which yields a precise estimate of the consumer welfare measure. ${ }^{26}$ On an annual basis for the US the annual consumers surplus is approximately $\$ 78.1$ million per year from the introduction of the new brand. This amount equals about $\$ 0.3136$ per person per year which is a sizeable amount of consumers surplus from the introduction of a new brand. Note that the virtual price of about $\$ 7.00$ is about 2 times the actual sales price of $\$ 3.50$ which seems to be a reasonable estimate. Since the own price elasticity is about -2.2 , the reservation price seems to be in about the correct range. ${ }^{27}$

The estimate of the virtual price of $\$ 7.14$ depends on the behavior of the estimated demand curve at the vertical axis (zero quantity). While significant price variation is observed in the data on the order of $50 \%$, prices as high as the virtual price are not observed. However, a lower bound estimate of the virtual price arises from constructing the supporting hyperplane (tangent) to the demand curve in Figures 1 and 2 at the actual average price of $\$ 3.48$ and observing the implied virtual price. So long as the demand curve is convex, this approach provides a lower bound estimate to the virtual price. Using this approach I find that the estimated lower bound virtual price varies between about $\$ 5.55$ and $\$ 5.94$ with an (asymptotic) standard error of about $\$ 0.15$. Thus, using the estimated lower bound I find that the average lower bound reservation price is about $65 \%$ higher than the

26 These exact welfare estimates and asymptotic standard errors use the method developed by Hausman and Newey (1993).

27 Use of this same estimation technique for other highly differentiated products often leads to significantly higher estimated elasticities. For instance, in Hausman et. al. (1994) we estimate own price elasticities for brands of beer, e.g. Budweiser. Miller. Miller Lite, in the range of about -4.0 to -6.2 . Thus, the data source and estimation technique do not seem to lead to too small elasticity estimates. 
average price of $\$ 3.48$. Thus, a significant amount of consumers surplus remains, even when a lower bound estimate is used.

Note that neglecting the effect of the new brand leads to an overstatement of the price index for cereal. If Apple-Cinnamon Cheerios is aggregated together with Honey-Nut Cheerios so they are considered to be a single brand, little effect is found beyond the slightly lower price of the new brand in the estimated average price of the two types of Cheerios. For a simple example, assume contrary to fact that all of Apple-Cinnamon Cheerios' share was taken from Honey-Nut Cheerios brand. Before the introduction the price index would be about $\$ 4.60$ while after the introduction of the new brand the price index would be about $\$ 3.57$ for a decrease of about $22 \%$ which is a sizeable reduction within the family segment. The decrease in the price index for the family segment is from $\$ 3.10$ to $\$ 2.88$, a decrease of $7.1 \%$. In the overall price index for cereal the effect would be a reduction of about 0.017 (or \$0.052) which is again significant. This estimate of about $1.7 \%$ would stay approximately the same when the assumption is relaxed that Apple-Cinnamon Cheerios takes all its share from Honey-Nut Cheerios. The approximate change in the price index can be calculated by taking Apple-Cinnamon Cheerios share of about $1.6 \%$ and multiply by the difference between the virtual price of about $\$ 7.00$ and the actual price of about $\$ 3.50$. The results will differ to the extent of price differences between Apple-Cinnamon Cheerios and the brands it takes share away from. If all brands had the same price the overall change in the price index will be about $1.5 \%$ or approximately the share of the new brand. Thus, to the extent that about $25 \%$ of cereal demand is from new brands over the past 10 years, and making the (perhaps unrealistic) assumption that the new brands sell for about the same average price as existing brands and that the estimate here would generalize to a reservation price of about 2 times the actual price, the overall price index for cereals which excludes the effects of new brands would be too high by about the overall share of new 
brands $-25 \%{ }^{28}$

V. Alternative Model Specifications for New Brand Introduction

An alternative model of brand choice is the Hotelling-Gorman-Lancaster model of brand choice by attributes. Here a product, such as a car, is described by its attributes, e.g. size, weight, and features such as airconditioning. ${ }^{29}$ A discrete choice model, either a logit model or probit model, is estimated and the demand for new brands is predicted as a function of the attributes. In a distinct contrast to these attribute models, I describe each brand uniquely by an indicator (dummy) variable. Indeed, it is difficult to conceive how I would describe Apple-Cinnamon Cheerios in terms of its attributes--perhaps the volume of apples and cinnamon along with other ingredients. Thus, it is readily recognized that for highly differentiated products, the discrete choice model specification based on product attributes may not be useable. ${ }^{30}$ Many economists find appealing the notion of "distance" incorporated in the attribute model. However, it is clear that no reasonable metric which describes "how close" attributes are exists; and, moreover, no aggregator across attributes exists. The commonly used assumptions of linearity seem ad hoc at best. Instead, the appropriate measure of distance between two goods is really their cross price elasticities which relates how closely consumers find the two goods to be substitutes.

28 This estimate is too high to the extent that exit of existing brands decreases consumers surplus for consumers still buying those brands. However, cereal brands are typically removed only when their market shares become extremely small because of the significant margins between price and marginal cost. Thus, the loss in consumers surplus due to exit will be extremely smali. However, I cannot estimate this decrease in consumers surplus due to lack of data.

29 An empirical specification of this model applied to new brands is given by Pakes et. al. (1993).

30 While I have often applied probit models to brand choice, see Hausman and Wise (1978), I realized the limitation of these models when I tried applying them to the choices among French champagnes. Somehow, the bubble content could never be made to come in significant in the probit specifications. 
Furthermore, the usual discrete choice model used, the logit model, suffers from the well known problem of the Independence of Irrelevant Alternative problem (IIA). The IIA problem typically leads to a vast overestimate of the consumers surplus from a new good because the model does not incorporate sufficiently the "similarities" with existing goods. Alternatively, the cross price elasticities of all goods with a given good are equal, see e.g. Hausman (1975). A more sophisticated specification, the nested logit model, can solve some of these problems but still suffers from the IIA problem at each level of choice. Thus, I consider another continuous demand specification, which bears quite remarkable similarities to the logit model, which has sometimes been used for new product demand estimation.

The most widely used specification in theoretical models of product differentiation is the CES utility function used by Dixit and Stiglitz (1977). The CES utility function takes the form:

$$
U\left(x_{1}, \ldots, x_{n}\right)=\left(\sum_{i=1}^{n} x_{1}^{p}\right)^{1 / p}
$$

The form of the CES utility function makes clear that all goods are treated equally with each other so that the IIA property is still present implicitly in the CES demand functions. ${ }^{31}$ Economic theorists have found the CES function to be analytically quite useful in studying product differentiation. However, the so-called symmetry property seems a poor guide to empirical reality where I know that Apple-Cinnamon Cheerios are a much closer substitute to Honey-Nut Cheerios than they are to Nabisco Shredded wheat or to Total. ${ }^{32}$ Given the implicit IIA property of the CES model, similar to the logit model, it will tend to overvalue variety. This overvaluation arises because

\footnotetext{
31 See Anderson et. al. (1992) for an insightful analysis of the similarities of the CES model and the logit model.

32 The CES model has been applied to new product introduction situations, see e.g. Feenstra (1994).
} 
the CES demand function does not recognize that some products are closer substitutes to other products. The CES demand function takes the form:

$$
x_{k}=\left[\frac{\sum_{i=1}^{n} x_{i}^{p}}{\sum_{i=1}^{n} p_{l}^{-p /(1-p)}}\right]^{1 / p} p_{k}^{-\frac{1}{1-p}}+e_{k}
$$

where the single parameter $\rho$ estimates substitution across goods. Indeed, solving for the cross price elasticities from equation (5.2) yields the finding that

$$
\frac{\partial x_{i}}{\partial p_{j}} \frac{p_{j}}{x_{i}}=\frac{\partial x_{k}}{\partial p_{j}} \frac{p_{j}}{x_{k}} \text { or } e_{i j}=e_{k j} \text { for alli,k,j. }
$$

which demonstrates the restrictiveness of the CES demand specification. The equality of cross price elasticities demonstrates that the CES demand function treats all goods similarly (symmetrically), and it cannot give a reliable basis to evaluate new goods. Furthermore, the own price elasticities depend only on the share of the particular good and the single parameter $\rho, a$ property without any empirical foundation. ${ }^{33}$

I now proceed to estimate the CES demand model of equation (2) using IV together with non-liner linear least squares (Non-linear 2SLS). I estimate $\rho$ $=.580$ (a.s.e. $=.00001)$. The estimate CES elasticity of substitution - 1/ ( 1 - $p)=2.13$. The CES demand curve is plotted in Figure 3. The virtual price is infinite, but I can still calculate the consumers surplus approximately as the area under the demand curve. The consumers estimate is about 3 times as

33 These properties of the own price and cross price elasticities are exactly analogous to the properties of the logit demand elasticities, c.f. Hausman (1975). Thus, the IIA property holds for both logit modes and for CES demand models. 
high as my previous estimate of $\$ 78.1$ million per year. Thus, as I expected, the CES model leads to an unrealistically high estimate of consumer welfare from a new brand introduction. Both the CES model and the logit model do not distinguish sufficiently with respect to the similarity and differences among brands. Thus, a more flexible demand model of the type I estimated above which allows for an unrestricted pattern of own price and cross price elasticities at the segment level appears to lead to much more realistic estimates of the virtual price and welfare effects of new brand introduction.

\section{New Brand Introduction with Imperfect Competition}

Up to this point I have followed the classical Hicks-Rothbarth approach to the evaluation of a new product. However, the implicit assumption that price equals marginal cost in the classical approach need not hold in most new product situations. Combined with the fact that most new brand introductions are done by multi-product firms with existing competing brands, the introduction of imperfect competition seems necessary for a more realistic evaluation. The basic idea of why a new product may change other prices is that when a firm solves for the profit maximizing price of its current brands it chooses the price where marginal revenue from a price increase equals marginal cost. When the multi-product firms introduces a new brand, some of the demand it would loose if it attempted to raise the price of its existing brands will now be lost to the new brand. Thus, while multi-brand firms always worry that a new brand will "cannibalize" the demand for an existing brand, the new brand allows the firm to raise its price on its existing brands. ${ }^{34}$

Once imperfect competition is allowed, the possibilities of different outcomes becomes quite large. I adopt the most widely used solution concept

i4 A counteracting effect can be that the new brand will cause the price of other firms brands to decrease because the new brand increases the own price elasticity of existing brands. The complicated interactions here are currently beyond the scope of economic theory to solve, although Tirole (1988) discusses many interesting examples which appear in the literature. 
for my analysis, Nash-Bertrand pricing. Thus, a single-product firm is assumed to set the price for a given product according to the marginal revenue equal marginal cost rule:

$$
\frac{p_{1}-m c_{1}}{p_{1}}=-\frac{1}{e_{11}}
$$

Equation (6.1) is the familiar equation that the markup of price over marginal cost is set equal to the inverse of the magnitude of the demand elasticity. Now in a multi-product firm setting when a firm changes the price of once good, it takes into account the effect on its other brands as well. Letting II be the firm's profit function, the first order conditions for the multiproduct firm become:

$$
\left[\frac{P_{j}}{\sum_{k=1}^{m} P_{k} q_{k}}\right] \frac{\partial \pi}{\partial P_{j}}=s_{j}+\sum_{k=1}^{m}\left[\frac{P_{k}-m c_{k}}{P_{k}} s_{k}\right] e_{k j}=0 \quad \text { for } j=1, \ldots, m
$$

where $q_{k}$ is the demand for brand $k, s_{k}$ is its share, and $e_{k j}$ are the cross price elasticities. Thus equation (6.2) makes clear the dependence of a price change on how close a given multi-product firm brands are in terms of their cross price elasticities.

I now express the first order conditions of equation (6.2) as a system of linear equations:

$$
s+E^{\prime} w=0
$$

where $s$ is the vector of revenues shares, $E$ is the matrix of cross price 
elasticities and $w$ is the vector of price-cost markups multiplied by the share (the term in brackets on the right hand side of equation (6.2)) which arise under the Nash-Bertrand assumption in equation (6.1). I solve for these individual terms of the markup equation by inversion of the matrix of cross elasticities:

$$
w=-\left(E^{\prime}\right)^{-1} s
$$

I can then use the individual elements of $w$ to determine the change in price after the new brand introduction to the extent that marginal costs remain constant. Note that while I have derived the change in price under NashBertrand assumptions, my analysis does not require this assumption. To the extent that pricing constraints will be decreased after the new brand is introduced, the analysis provides a lower bound on expected price changes, absent new entry by competitors.

I now apply the Nash-Bertrand model to the introduction of AppleCinnamon Cheerios. Remember that General Mills was already selling regular Cheerios and Honey-Nut Cheerios when it introduced Apple-Cinnamon Cheerios in 1989. Thus, General Mills (GM) has to take into account the negative effect ("cannibalization") that the introduction of Apple-Cinnamon Cheerios will have on the demand for its other brands when deciding on a possible new brand. However, introduction of new brands also allows General Mills to price higher for its existing brands because when it raises their prices part of the demand that it loses will go to the new brand, Apple-Cinnamon Cheerios. Thus, the welfare analysis must also be adjusted to take account of the imperfect competition which exists in the cereals market. Using the Nash-Bertrand assumption. this effect tends to lead to higher pricing for each of the other General Mills' brands.

Using self-and cross-elasticities and pound shares for General Mills' brands in the family segment given in Table 3. I calculate Table 7 : 
Table 7: Nash-Bertrand Pricing of General Mills Family Segment Brands

$\begin{array}{lll} & \underline{\text { Cheerios }} & \underline{\text { HN Cheerios }} \\ \text { P-C margin } & 0.5268 & 0.5203 \\ \text { P-C margin w/o AC Cheerios } & 0.5251 & 0.5096 \\ \text { P-C margin if brand were independent } & 0.5193 & 0.5050\end{array}$

These calculations are done using equations (6.1)-(6.4) which calculate the markups over marginal cost which are profit maximizing for General Mills under the Nash-Bertrand assumption that other firms, e.g. Kellogg, will not change their prices in response to the introduction of Apple-Cinnamon Cheerios. The values from the first two rows imply a hypothetical price change of $\$ 0.0095$ for Cheerios and $\$ 0.0787$ for Honey-Nut Cheerios. The increase in the markup for Cheerios is only $0.32 \%$ while the markup for Honey-Nut Cheerios increases by $3.0 \%$ which is expected because Apple-Cinnamon Cheerios are a closer substitute for Honey-Nut Cheerios than for regular Cheerios.

I now account for the increase in prices of the other two Cheerios brands when Apple-Cinnamon Cheerios are introduced by General Mills. The average (per-city weekly) pound sales for Cheerios and Honey-Nut Cheerrios are 93,738 and 47,215 respectively. This effect implies a first-order decrease in consumer surplus (per-city weekly) of $\$ 890+\$ 3715=\$ 4605$ (as compared to the $\$ 32,000-44,000$ consumer surplus estimates). Therefore, the net gain in consumers surplus is $\$ 32,000-4605=\$ 27,395$, or an amount $85.6 \%$ as high as the Hicksian calculation. On an annual basis the gain in consumers surplus is $\$ 66.8$ MM per year (equivalently, $\$ .268$ per person per year). Thus, while the gain to the new brand introduction is still sizeable, it must be adjusted downward. Using the assumption on overall new brand introduction, instead of the CPI for cereals being too high on the order of $25 \%$ under the perfect competition assumption, the introduction of imperfect competition would reduce the overstatement of the cereal CPI to about 20\%. This amount is still large enough to be important and demonstrates the importance of considering new brand introduction in calculation of economic welfare and consumer price 
indices.

The introduction of imperfect competition in evaluating new goods is a marked departure from the classical Hicks-Rothbarth approach. Imperfect competition brings with it supply (cost) considerations which are typically absent from cost-of-living theory which is typically concerned only with demand factors. The approach I have taken is to calculate the theoretical effect of imperfect competition under a particular model assumption, NashBertrand competition. Another approach, left for future research, is to analyze the actual effect on prices of the introduction of a new brand. Data considerations do not permit the analysis here, because the Nielsen data I have does not cover the period prior to the introduction of Apple-Cinnamon Cheerios. However, now that detailed store level micro data are available, such a study would be extremely interesting for the current subject of welfare effects of new produce introduction as well as for the broader area of competitive interaction in industrial organization theory.

\section{Conclusion}

The correct economic approach to the evaluation of new goods has been known for over 50 years since Hicks' pioneering contribution. However, it has not been implemented by government statistical agencies, perhaps because of its complications and data requirements. Data are now available. The impact of new goods on consumer welfare appear to be significant according to the demand estimates of this paper. According to rough calculations in this paper, the CPI for cereal may be too high by the order of $25 \%$ because it does not account for new cereal brands. An estimate this large seems worth worrying about.

However, the classical theory propounded by Hicks leaves out an important potential element. In imperfect competition which characterizes all differentiated product industries, introduction of a new brand may permit a muiti-product firm to raise the prices of its other brands. The price 
increases for existing brands will decrease the welfare increasing effects of the new brand. According to my estimate for the example of Apple-Cinnamon Cheerios, the imperfect competition effect will reduce consumer welfare by about 15\% compared to the perfect competition situation. Nevertheless, the welfare effect of the new brand introduction under imperfect competition is still significant--about $20 \%$ according to my rough calculations. Thus, I find that new brand introduction should often be considered favorable by most economists given its significant welfare increasing effects. 
Anderson, S.P., A. de Palma, and J-F. Thisse, Discrete Choice Theory of Product Differentiation, Cambridge, MA: The MIT Press, (1992).

Blackorby, $C$, et al, Duality, Separability, and Functional Structure, (New York, NY: American Elsevier), (1978).

Breusch, T.S., G.E Mizon, and P. Schmidt, "Efficient Estimation Using Panel Data," Econometrica, 57, (1989).

Burtless, G. and J. Hausman, "The Effect of Taxation on Labor Supply: Evaluating the Gary Negative Income Tax Experiment," Journal of Political Economy, (December 1978).

Deaton, A. and J. Muellbauer, Economics and Consumer Behavior, Cambridge: Cambridge University Press, (1980).

Diewert, W.E., "Essays in Index Number Theory: An Overview of Volume 1," Discussion Paper No.: 92.31 , Canada: University of British Columbia, (1992).

Dixit, A. and J.E. Stiglitz, "Monopolistic Competition and Optimum Product Diversity," American Economic Review, 67, pp. 297-308, (1977).

Feenstra, R.C., "New Product Varieties and the Measurement of International Prices," American Economic Review, 84, pp. 157-177, (1984).

Fixler, D., "The Consumer Price Index: Underlying Concepts and Caveats", Monthly Labor Review, December, pp. 3-12, (1993).

Gorman, W., "Two Stage Budgeting," mimeo, (1971).

Hauman, J., "Project Independence Report: A Review of U.S. Energy Needs up to i985," Bell Journal of Economics, (1975).

Hausman, J., "Specification Tests in Econometrics," Econometrica, 46, (1978).

Hausman, J., "The Effect of Wages, Taxes, and Fixed Costs on Women's Labor Force Participation," Journal of Public Economics, (1980).

Hausman, J., "Exact Consumer Surplus and Deadweight Loss," American Economic Review, 71, (1981).

Hausman, J., G. Leonard, And J. D. Zona, "Competitive Analysis with Differentiated Products", Annales D'Economie et de Statistique, (1994).

Hausman, J. and W. Newey, "Nonparametric Estimation of Exact Consumers Surplus and Deadweight Loss." forthcoming Econometrica, (1993).

Hausman, $J$. and $W$. Taylor, "Panel Data and Unobservable Individual Effects," Econometrica, 49, (1981).

Hausman, J. and D. Wise, "A Conditional Probit Model for Qualitative Choice," Econometrica, 46. (1978).

Hicks, J.R., "The Valuation of the Social Income," Economic Journal, (1940).

Judd, K.L. "Credible Spatial Preemption," Rand Journal of Economics, 16, 2 , pp. 153-166. (1985). 
Konüs, A.A, "The Problem of the True Index of the cost-of-Living," (in Russian), The Economic Bulletin of the Institute of Economic Conjuncture, (Moscow), No. 9-10, Pp. 64-71, 1924. English translation: Econometrica, 7, pp. 10-29, (1939).

Neary, J.P. and K.W.S. Roberts, "The Theory of Household Behavior Under Rationing, European Economic Review, (1980).

Pakes, A., S. Berry, and J. Levinsohn, "Price Indexes and the Analysis of Environmental Change," American Economic Review, 83, Pp. 240-246, (1993). Polak, R., The Theory of the Cost-of-Living Index, Oxford: Oxford University
Press. (1989)

Robinson, $J$, The Economics of Imperfect Competition, London: Macmillan, (1933).

Rothbarth, E., "The Measurement of Changes in Real Income under conditions of Rationing," Review of Economic Studies, pp. 100-107, (1941).

Scherer, F.M., "The Breakfast Cereal Industry," in W. Adams (ed.), The Structure of American Industry ( $6 \mathrm{th}$ ed.), New York, NY: Macmilian, (1982).

Schmalensee, R., "Entry Deterrence in the Ready-to-East Breakfast Cereal Industry," Bell Journal of Economics, (1978).

Sutton, J Sunk Costs and Market Structure, Cambridge, MA: The MIT Press, (1991).

Tirole, J., The Theory of Industrial Organization, Cambridge, MA: The MIT Press, (1988).

Urban, G.L., G.M. Katz, T.E. Hatch, and A.J. Silk, "The ASSESSOR Pre-test Market Evaluation System," Interfaces, 13, pp. 38-59, (1983). 
Table 3: SUR Estimates for Family Seganent Brand Demand

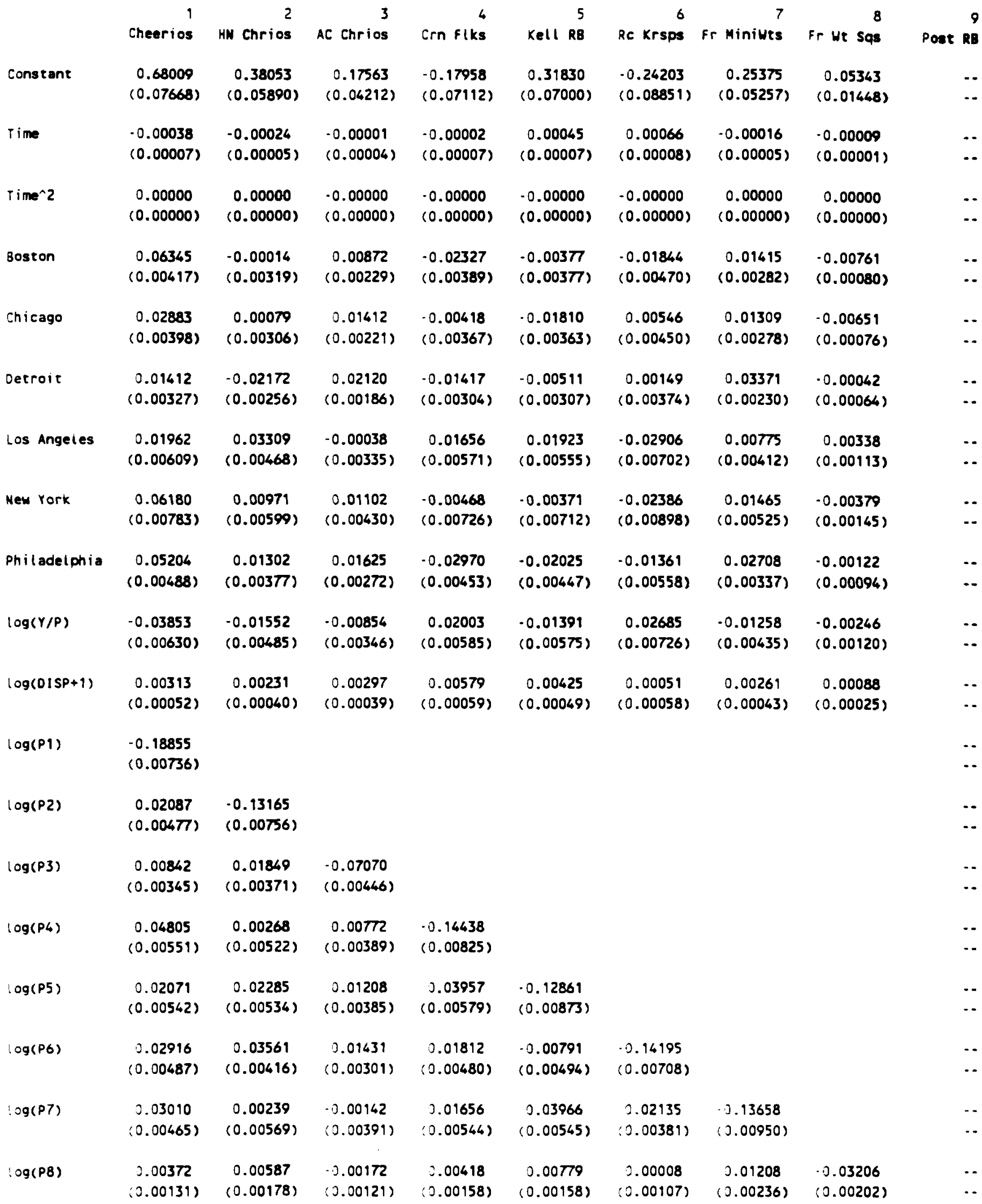




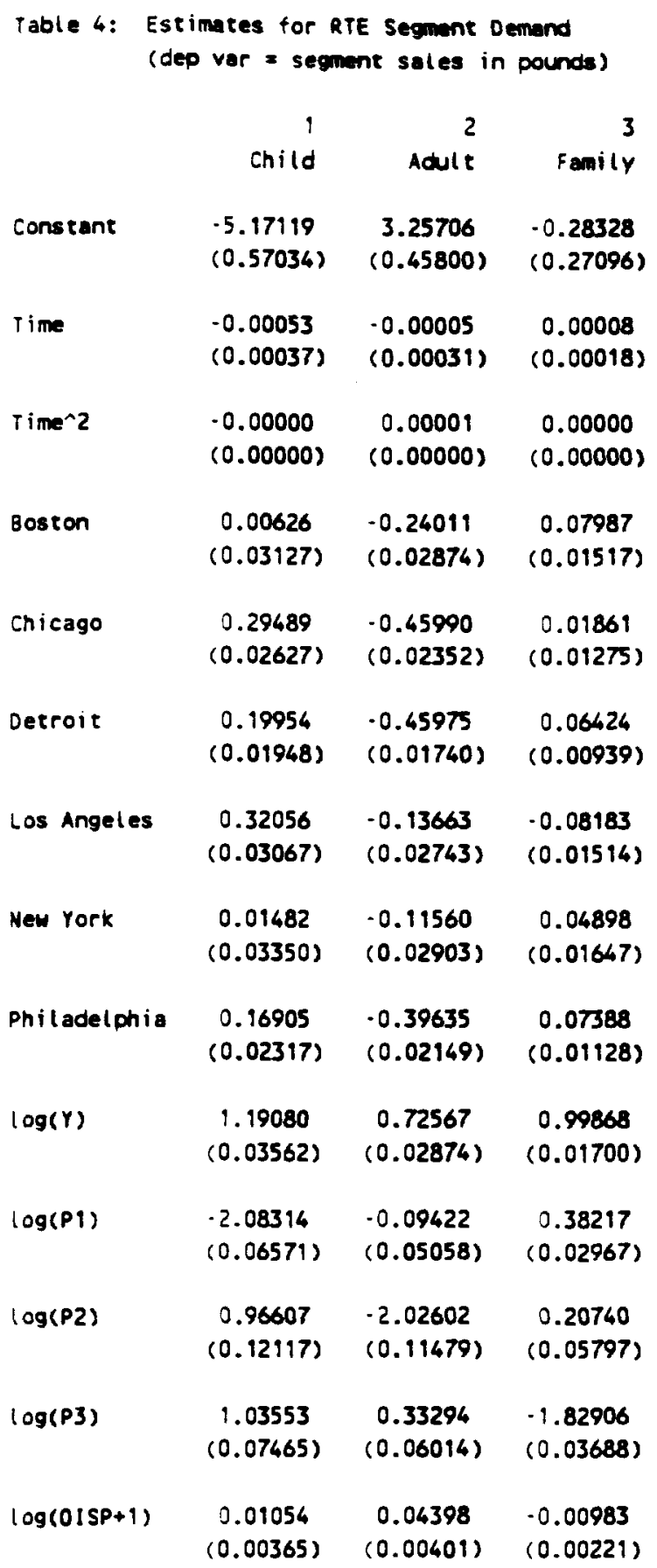




\begin{tabular}{|c|c|c|c|c|c|c|c|c|c|}
\hline HM Chrios & $\begin{array}{c}0.21637 \\
(0.03686)\end{array}$ & $\begin{array}{l}-1.83838 \\
(0.05397)\end{array}$ & $\begin{array}{c}0.14169 \\
(0.02562)\end{array}$ & $\begin{array}{c}0.00390 \\
(0.03613)\end{array}$ & $\begin{array}{c}0.18550 \\
(0.03750)\end{array}$ & $\begin{array}{c}0.21253 \\
(0.03263)\end{array}$ & $\begin{array}{c}0.04330 \\
(0.03967)\end{array}$ & $\begin{array}{c}0.04616 \\
(0.01197)\end{array}$ & $\begin{array}{c}0.09625 \\
(0.03263)\end{array}$ \\
\hline AC Chrios & $\begin{array}{c}0.23945 \\
(0.06477)\end{array}$ & $\begin{array}{c}0.34899 \\
(0.06330)\end{array}$ & $\begin{array}{l}-2.11677 \\
(0.07406)\end{array}$ & $\begin{array}{c}0.10597 \\
(0.06451)\end{array}$ & $\begin{array}{c}0.23973 \\
(0.06616)\end{array}$ & $\begin{array}{c}0.19848 \\
(0.05520)\end{array}$ & $\begin{array}{c}0.01366 \\
(0.06708)\end{array}$ & $\begin{array}{l}-0.02100 \\
(0.01993)\end{array}$ & $\begin{array}{c}0.12936 \\
(0.06950)\end{array}$ \\
\hline Crn fliks & $\begin{array}{c}0.23185 \\
(0.04859)\end{array}$ & $\begin{array}{l}-0.03254 \\
(0.04108)\end{array}$ & $\begin{array}{c}0.02883 \\
(0.02952)\end{array}$ & $\begin{array}{l}-1.99465 \\
(0.06003)\end{array}$ & $\begin{array}{c}0.23222 \\
(0.04533)\end{array}$ & $\begin{array}{c}0.16056 \\
(0.03831)\end{array}$ & $\begin{array}{c}0.07898 \\
(0.04307)\end{array}$ & $\begin{array}{c}0.02246 \\
(0.01186)\end{array}$ & $\begin{array}{c}0.13165 \\
(0.06 \text { (46) })\end{array}$ \\
\hline Fr Miniwts & $\begin{array}{c}0.43609 \\
(0.05608)\end{array}$ & $\begin{array}{c}0.07708 \\
(0.06460)\end{array}$ & $\begin{array}{c}0.00939 \\
(0.04498)\end{array}$ & $\begin{array}{c}0.16386 \\
(0.06371)\end{array}$ & $\begin{array}{c}0.48235 \\
(0.06381)\end{array}$ & $\begin{array}{c}0.20255 \\
(0.04921)\end{array}$ & $\begin{array}{l}-2.46950 \\
(0.11340)\end{array}$ & $\begin{array}{c}0.14003 \\
(0.02669)\end{array}$ & $\begin{array}{c}0.09692 \\
(0.06562)\end{array}$ \\
\hline Fr Wt Sas & $\begin{array}{c}0.37740 \\
(0.09617)\end{array}$ & $\begin{array}{c}0.45906 \\
(0.12191)\end{array}$ & $\begin{array}{l}-0.08636 \\
(0.08357)\end{array}$ & $\begin{array}{c}0.26062 \\
(0.11035)\end{array}$ & $\begin{array}{c}0.58179 \\
(0.11175)\end{array}$ & $\begin{array}{l}-0.03396 \\
(0.08260)\end{array}$ & $\begin{array}{c}0.86314 \\
(0.16566)\end{array}$ & $\begin{array}{l}-3.16485 \\
(0.13832)\end{array}$ & $\begin{array}{l}-0.09011 \\
(0.11552)\end{array}$ \\
\hline ost RB & $\begin{array}{l}-0.10461 \\
(0.12414)\end{array}$ & $\begin{array}{c}0.11474 \\
(0.10689)\end{array}$ & $\begin{array}{c}0.08315 \\
(0.07742)\end{array}$ & $\begin{array}{c}0.23661 \\
(0.11177)\end{array}$ & $\begin{array}{l}-0.35988 \\
(0.12199)\end{array}$ & $\begin{array}{c}0.73072 \\
(0.11060)\end{array}$ & $\begin{array}{c}0.07025 \\
(0.10844)\end{array}$ & $\begin{array}{l}-0.03721 \\
(0.03036)\end{array}$ & $\begin{array}{l}-2.51616 \\
(0.15731)\end{array}$ \\
\hline
\end{tabular}

$\begin{array}{llllllllll}\text { Meen Shares } & 0.21617 & 0.15026 & 0.06193 & 0.14243 & 0.13117 & 0.13539 & 0.09067 & 0.01475 & 0.05722\end{array}$ 


\begin{tabular}{|c|c|c|c|c|c|c|c|c|c|}
\hline Hn Chrios & $\begin{array}{c}0.03154 \\
(0.03080)\end{array}$ & $\begin{array}{l}-1.98037 \\
(0.05808)\end{array}$ & $\begin{array}{c}0.21247 \\
(0.06808)\end{array}$ & $\begin{array}{l}-0.21316 \\
(0.04805)\end{array}$ & $\begin{array}{c}0.07136 \\
(0.04861)\end{array}$ & $\begin{array}{c}0.00079 \\
(0.05199)\end{array}$ & $\begin{array}{l}-0.05929 \\
(0.06752)\end{array}$ & $\begin{array}{c}0.32712 \\
(0.12696)\end{array}$ & $\begin{array}{l}-0.16719 \\
(0.11663)\end{array}$ \\
\hline AC Chrios & $\begin{array}{c}0.01747 \\
(0.01919)\end{array}$ & $\begin{array}{c}0.08317 \\
(0.02690)\end{array}$ & $\begin{array}{l}-2.17304 \\
(0.07525)\end{array}$ & $\begin{array}{l}-0.04561 \\
(0.03144)\end{array}$ & $\begin{array}{c}0.05287 \\
(0.03224)\end{array}$ & $\begin{array}{l}-0.00824 \\
(0.03111)\end{array}$ & $\begin{array}{l}-0.04682 \\
(0.04591)\end{array}$ & $\begin{array}{l}-0.14074 \\
(0.08462)\end{array}$ & $\begin{array}{l}-0.03304 \\
(0.05000)\end{array}$ \\
\hline Crn Flks & $\begin{array}{c}0.07484 \\
(0.03008)\end{array}$ & $\begin{array}{l}-0.13069 \\
(0.03850)\end{array}$ & $\begin{array}{l}-0.02343 \\
(0.06503)\end{array}$ & $\begin{array}{l}-2.16585 \\
(0.06155)\end{array}$ & $\begin{array}{c}0.15311 \\
(0.04759)\end{array}$ & $\begin{array}{l}-0.01918 \\
(0.04555)\end{array}$ & $\begin{array}{c}0.03460 \\
(0.06405)\end{array}$ & $\begin{array}{c}0.13556 \\
(0.10926)\end{array}$ & $\begin{array}{l}-0.03062 \\
(0.19573)\end{array}$ \\
\hline Re Krsps & $\begin{array}{l}-0.02457 \\
(0.03109)\end{array}$ & $\begin{array}{c}0.08459 \\
(0.03368)\end{array}$ & $\begin{array}{c}0.07548 \\
(0.05384)\end{array}$ & $\begin{array}{l}-0.00219 \\
(0.04071)\end{array}$ & $\begin{array}{l}-0.21300 \\
(0.04308)\end{array}$ & $\begin{array}{l}-2.17246 \\
(0.06354)\end{array}$ & $\begin{array}{c}0.07967 \\
(0.04854)\end{array}$ & $\begin{array}{l}-0.15285 \\
(0.07886)\end{array}$ & $\begin{array}{c}0.47670 \\
(0.11284)\end{array}$ \\
\hline Fr Miniwts & $\begin{array}{c}0.10797 \\
(0.02567)\end{array}$ & $\begin{array}{l}-0.04239 \\
(0.04189)\end{array}$ & $\begin{array}{l}-0.06872 \\
(0.06978)\end{array}$ & $\begin{array}{l}-0.03001 \\
(0.04629)\end{array}$ & $\begin{array}{c}0.24504 \\
(0.04735)\end{array}$ & $\begin{array}{l}-0.00943 \\
(0.04162)\end{array}$ & $\begin{array}{l}-2.55178 \\
(0.11603)\end{array}$ & $\begin{array}{c}0.78352 \\
(0.16839)\end{array}$ & $\begin{array}{l}-0.09987 \\
(0.11360)\end{array}$ \\
\hline fr We Sqs & $\begin{array}{c}0.01315 \\
(0.00656)\end{array}$ & $\begin{array}{c}0.03020 \\
(0.01217)\end{array}$ & $\begin{array}{l}-0.03440 \\
(0.02015)\end{array}$ & $\begin{array}{c}0.00473 \\
(0.01216)\end{array}$ & $\begin{array}{c}0.05064 \\
(0.01274)\end{array}$ & $\begin{array}{l}-0.02772 \\
(0.01045)\end{array}$ & $\begin{array}{c}0.12664 \\
(0.02682)\end{array}$ & $\begin{array}{l}-3.17781 \\
(0.13863)\end{array}$ & $\begin{array}{l}-0.06489 \\
(0.03082)\end{array}$ \\
\hline Post RB & $\begin{array}{l}-0.02239 \\
(0.02908)\end{array}$ & $\begin{array}{c}0.04018 \\
(0.03840)\end{array}$ & $\begin{array}{c}0.07738 \\
(0.06837)\end{array}$ & $\begin{array}{c}0.06288 \\
(0.04415)\end{array}$ & $\begin{array}{l}-0.16016 \\
(0.04953)\end{array}$ & $\begin{array}{c}0.26985 \\
(0.04521)\end{array}$ & $\begin{array}{c}0.04499 \\
(0.06495)\end{array}$ & $\begin{array}{l}-0.14035 \\
(0.11447)\end{array}$ & $\begin{array}{l}-2.62151 \\
(0.15447)\end{array}$ \\
\hline
\end{tabular}




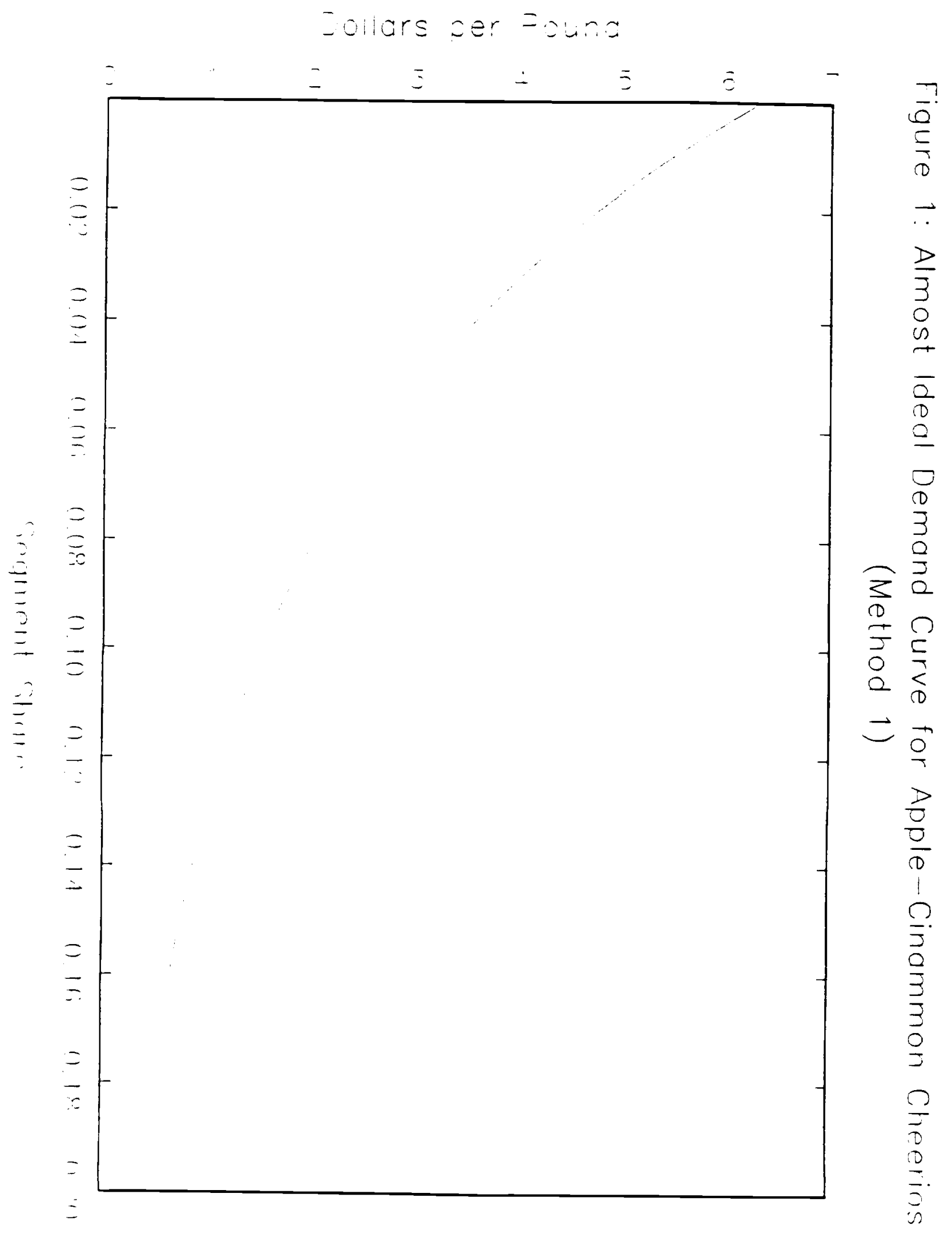




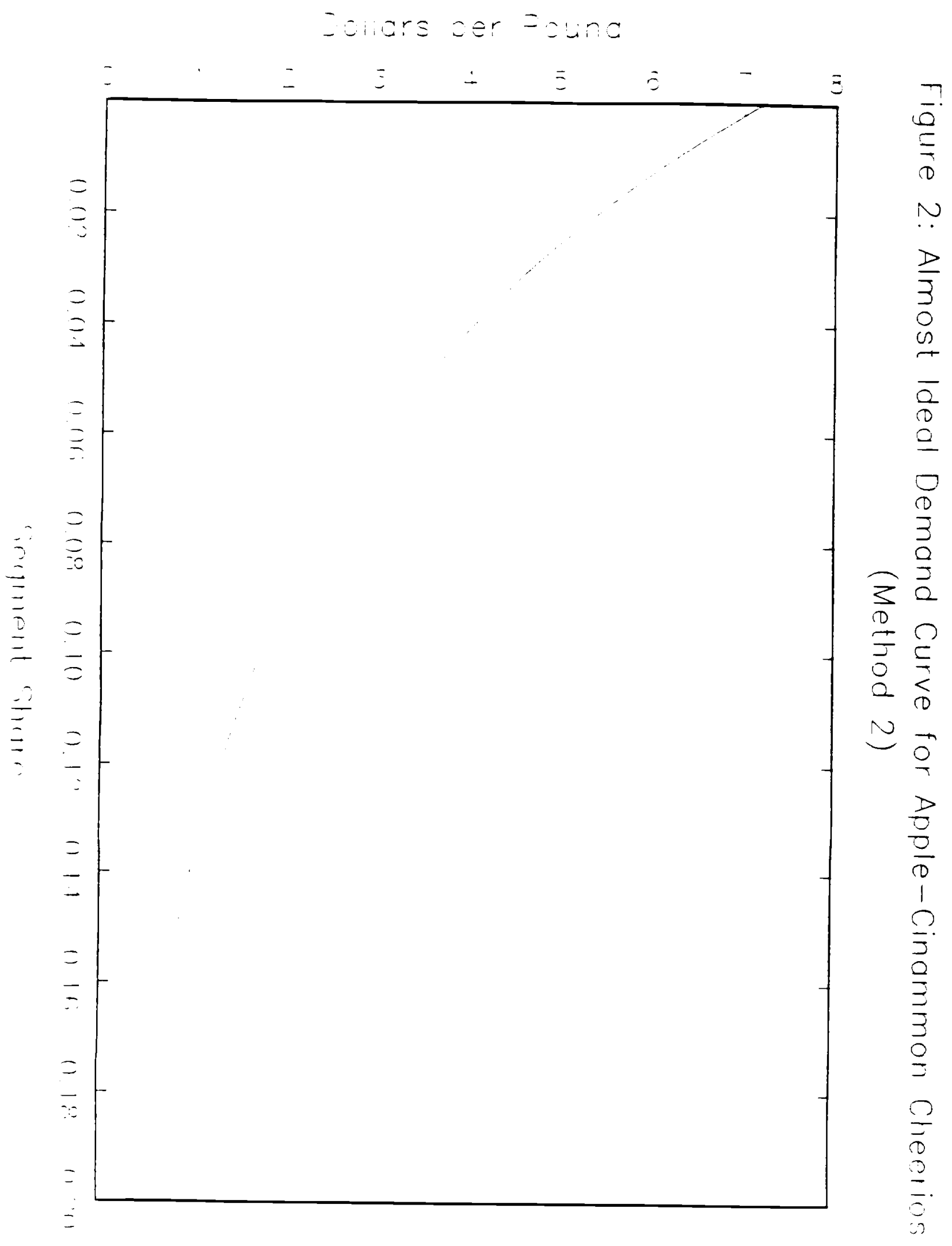


Figure 3: CES Demand Curve for Family Segment Brand

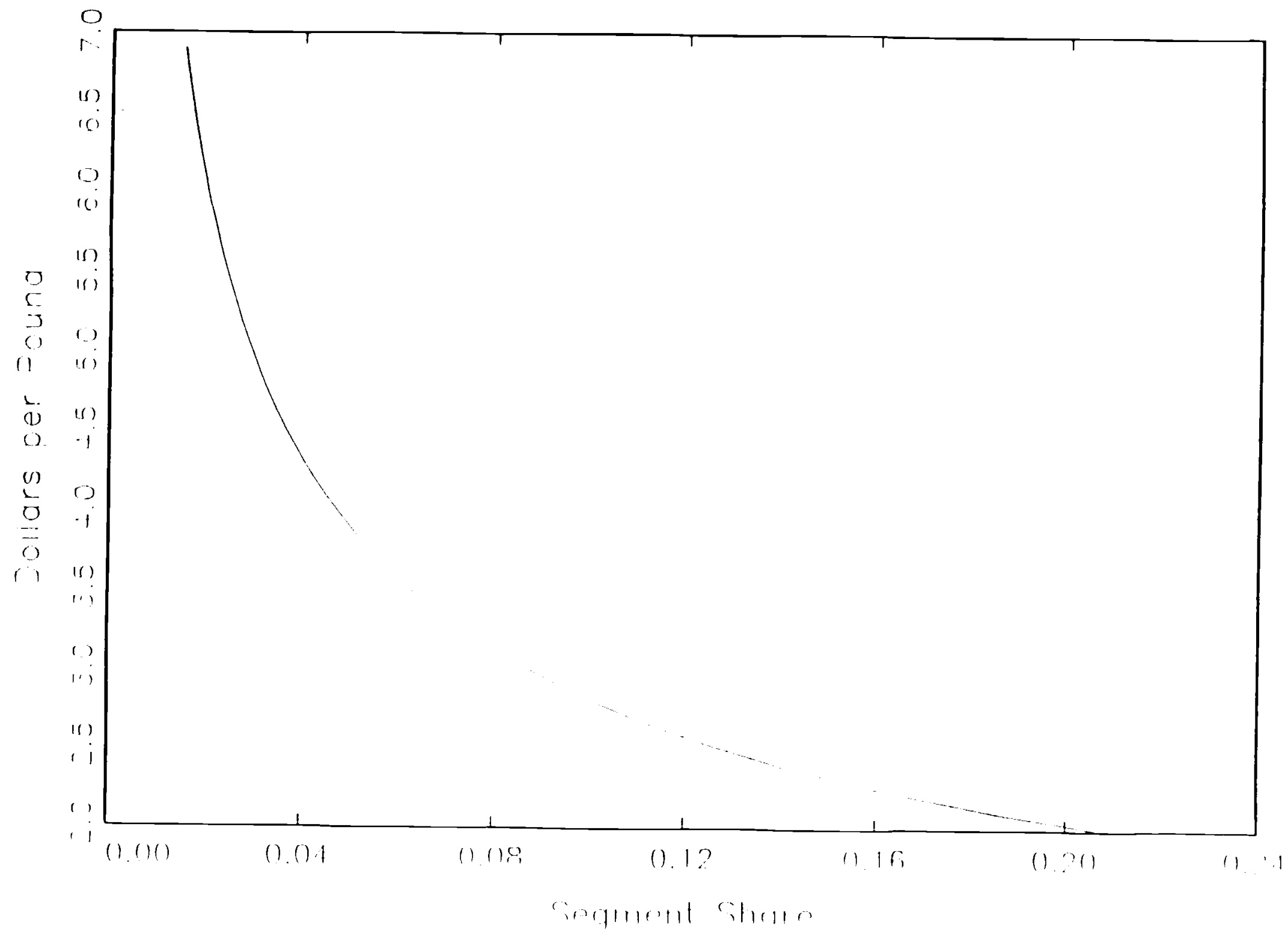

